\title{
SKEMA FIRE ASSAY DAN ICP-MS PADA PENGUKURAN KADAR PALADIUM DALAM SAMPEL BATUAN
}

\section{FIRE ASSAY AND ICP-MS SCHEMES ON THE PALLADIUM LEVELS MEASUREMENT IN ROCK SAMPEL}

\author{
Ronaldo Irzon ${ }^{a}$, Kurnia ${ }^{a}$ \\ a Pusat Survei Geologi, JI. Diponegoro 57. Bandung \\ e-mail: ronaldoirzon18@gmail.com
}

\begin{abstract}
Abstrak
Paladium (Pd) adalah anggota Platinum Grup Element yang berjumlah kecil di kerak Bumi, namun memiliki harga jual yang tinggi. Logam ini sangat dibutuhkan oleh industri otomotif, industri pesawat ruang angkasa, dan industri perhiasan. Akurasi pengukuran Pd yang baik pada sampel diperlukan untuk mendukung industri terkait. Penelitian ini bertujuan untuk menjabarkan akurasi pengukuran Pd yang memanfaatkan skema fire assay dalam pra-konsentrasi dan ICP-MS sebagai perangkat pengukuran. Sampel yang dipergunakan adalah bahan internal standar Serpentin milik Laboratorium Geologi. Limit deteksi cukup rendah pada 1,0057 ppb yang ditentukan melalui skema regresi linear. Stabilitas kinerja perangkat sangat baik yang ditunjukkan oleh rentang deviasi $0-1,96 \%$. Prosedur fire assaying yang belum sempurna disimpulkan menjadi penyebab perbedaan hasil pengukuran kadar Pd pada sampel. Rangkaian proses dalam studi ini dinilai akurat yang mengacu pada besaran spike recovery $<112 \%$. Studi ini dapat dikembangkan dengan memperbesar rentang kalibrasi analisis agar dapat mengakomodasi kisaran jumlah analit yang lebih luas pada sampel.
\end{abstract}

Kata kunci: analisis Pd, fire assay, ICP-MS, industri

\begin{abstract}
Palladium $(P d)$ is a Platinum Group Element member with small abundance in the Earth's crust, but has a high price. The metal is needed by the automotive industry, the space ship industry, and the jewellery industry. Accurate measurement of Pd measurements on samples is needed to support the related industries. This study aims to describe the accuracy of $P d$ measurements using the fire assay pre-concentration scheme and ICP$M S$ as a measurement device. The used sample was Serpentine internal inhouse standard material belonging to the Geology Laboratory. The detection limit is quite low at $1.0057 \mathrm{ppb}$ which is determined through a linear regression scheme. The stability of device performance is very good as indicated by the range of deviations from $0-1.96 \%$. The incomplete fireassaying procedure was concluded to be the cause of differences in the measurement results of $\mathrm{Pd}$ levels in the sample. The series of processes in this study are considered accurate, which refers to the spike recovery of $<112 \%$. This study can be developed by enlarging the range of calibration analyses to accommodate a wider range of analytes in the sample.
\end{abstract}

Key Words: Pd analysis, fire assay, ICP-MS, industry

Diterima (received ) : 27 Desember 2018 , Direvisi (revised ) : 28 Juni 2019 ,

Disetujui (accepted) : 08 Juli 2019 


\section{PENDAHULUAN}

Paladium (Pd) merupakan salah satu logam pada kelompok Platinum Group Metals (PGM) bersama dengan platina (Pt), rodium ( $\mathrm{Rh}$ ), iridium (Ir), osmium (Os), dan rutenium $(\mathrm{Ru})$. Logam-logam kelompok ini cenderung hadir bersama akibat kemiripan sifat kimia dan fisikanya. Akibat kelimpahannya yang rendah pada kerak bumi, PGM merupakan material yang mahal ${ }^{1}$. Stok PGM yang rendah di pasaran berpengaruh terhadap ketidakstabilan harganya ${ }^{2)}$. Dari sudut pandang ilmu kebumian, PGM cenderung berafiliasi dengan batuan ultramafik hingga mafik, bersifat siderofil-kalkofil, dan sering ditemukan pada batuan jenuh sulfida ${ }^{1,3,4,5,6)}$. Indonesia bagian timur dapat dikategorikan sebagai wilayah dengan berpotensi PGM karena terdeteksi memiliki banyak singkapan batuan ultramafik, seperti: Sulawesi Tenggara $^{7)}$, Halmahera ${ }^{8)}$, dan Papua bagian timur9).

Meski harganya cukup tinggi, paladium berfungsi strategis dalam dunia industri modern. Paladium dibutuhkan sebagai catalytic converter dalam industri otomotif ${ }^{10)}$. Perpaduan paladium dan perak merupakan elektroda penting dalam industri elektronik. Selain itu, campuran emas, nikel, perak, dan paladium dikenal sebagai 'emas putih' dalam industri perhiasan. Campuran paladium dan yttrium terbukti dapat meningkatkan sensitifitas Surface Acoustic Wave (SAW) sensors pada industri pesawat luar angkasa ${ }^{11)}$. Sebagai konsekuensi kandungannya yang rendah di alam, beragam metode analisis telah dikembangkan agar dalam mengukur konsentrasi paladium dalam sampel secara akurat. Proses klorinasi basah yang dilanjutkan dengan ekstraksi telah dicoba untuk ekstraksi emas, perak, platina, paladium, dan selenium ${ }^{12)}$. Fotoreduksi dengan laser telah dimanfaatkan pada recovery paladium dalam limbah nuklir ${ }^{13)}$.

Sebagai fasilitas analisis yang telah terstandarisasi ISO/IEC 17025:2008, Laboratorium Pusat Survei Geologi telah beberapa kali melakukan proyek penelitian terkait standardisasi mengenai analisis logam dasar, logam mulia, maupun kelompok PGM. Fasilitas pengujian ini memiliki beragam perangkat pengukuran kadar logam dalam suatu bahan. Atomic absorbance spectrometry (AAS) telah dimanfaatkan untuk menentukan beberapa tingkat recovery platina berdasarkan variasi
$\mathrm{pH}$ dan temperatur ${ }^{14)}$. Penelitian lainnya telah membahas akurasi analisis kadar nikel antara AAS, inductively coupled plasma mass spectrometry (ICP-MS), dan $X$-ray spectrometry $(\mathrm{XRF})^{15)}$. Selain perangkat pengukuran kadar logam/ elemen, laboratorium ini juga dilengkapi oleh perangkat fire assay untuk pra-konsentrasi material yang berkelimpahan sangat kecil di alam. Komposisi fluks terbaik dalam aplikasi fire assay terkait pengukuran kadar emas telah dibahas pada studi sebelumnya ${ }^{16)}$.

Penelitian ini bertujuan untuk menjabarkan penggunaan fire assay dalam pra-konsentrasi paladium dengan pemanfaatan ICP-MS sebagai perangkat pengukuran. Sampel yang dipergunakan adalah Serpentin sebagai bahan acuan standar internal yang berasal dari batuan ultramafik dari wilayah Sulawesi Tenggara. Hasil penelitian dapat mendukung industri terkait paladium di Indonesia. Berdasarkan kadar paladium yang rendah di alam dan sampel bukan berasal dari daerah dengan kadar paladium yang terbukti ekonomis, maka studi ini tidak menganalisis sampel tanpa pra-konsentrasi fire assay.

\section{BAHAN DAN METODE}

Sampel yang dipergunakan dalam studi ini adalah batuan terubah yang disebut sebagai Serpentin dari daerah Karangsambung, Provinsi Jawa Tengah. Sampel tersebut telah dikeringkan dan digerus hingga lolos ayakan 200 mesh. Bahan standar untuk kalibrasi dibuat dengan pengenceran larutan Pd 1000 ppm dalam $\mathrm{HCl}(10 \%)$ dari Spex CertiPrep, Jerman. Seluruh proses pengenceran dilaksanakan dengan ultrapure water untuk meminimalkan gangguan analisis.

Perangkat ICP-MS dipilih karena memang cukup akurat untuk menganalisis kadar elemen pada sampel bahkan hingga limit part per billion (ppb). Karena paladium diketahui sebagai logam dengan konsentrasi alami sangat rendah, maka skema fire assay juga diterapkan dalam studi ini dalam proses pra-konsentrasi. Meski membutuhkan waktu yang lama, pemanfaatan tungku pembakaran dalam skema fire assay terbukti dapat menaikkan konsentrasi logam pada bahan yang dianalisis berdasarkan titik leburnya seperti pada beberapa penelitian sebelumnya ${ }^{14,17,18)}$. Selain itu, skema fire assay menggunakan temperatur tinggi $>800^{\circ} \mathrm{C}$ sehingga dibutuhkan perangkat 
pelindung khusus saat menjalankannya (Gambar 1a). Sampel Serpentin yang digunakan telah berbentuk bubuk dengan ukuran 200 mesh sehingga tidak memerlukan proses pengeringan dan penggerusan.

Metode spiking, yang juga dikenal sebagai uji akurasi dua titik, diadaptasi pada studi ini karena dinilai tepat terhadap konsentrat analit yang berjumlah sangat sedikit pada suatu sampel ${ }^{19,20,21)}$. Sampel Serpentin dibuat dalam empat skema, yaitu:

Serpentin(I) tanpa penambahan bahan standar mengandung paladium (spiking), Serpentin(II) tanpa spiking, Serpentin(I) dengan spiking 2,5 ppm $\mathrm{Pd}$, dan Serpentin(II) dengan spiking 5 ppm Pd. Oleh karena itu, empat sampel dari Serpentin dipersiapkan untuk ditimbang dan melalui proses fire assay.

Secara garis besar metode fire assay terdiri tiga tahap, yaitu: pencampuran fluks, reaksi fusi, dan kupelasi. Sampel ditimbang untuk kemudian dicampurkan dengan fluks ke dalam plastik polyetilen. Natrium karbonat $\left(\mathrm{Na}_{2} \mathrm{CO}_{3}, 60 \mathrm{~g}\right)$, litharge $(\mathrm{PbO}, 40 \mathrm{~g})$, oksida silika $\left(\mathrm{SiO}_{2}, 20 \mathrm{~g}\right)$, boraks $\left(\mathrm{Na}_{2} \mathrm{~B}_{4} \mathrm{O}_{7}, 25 \mathrm{~g}\right)$, kalsium florida $\left(\mathrm{CaF}_{2}, 10 \mathrm{~g}\right)$, dan tepung (5

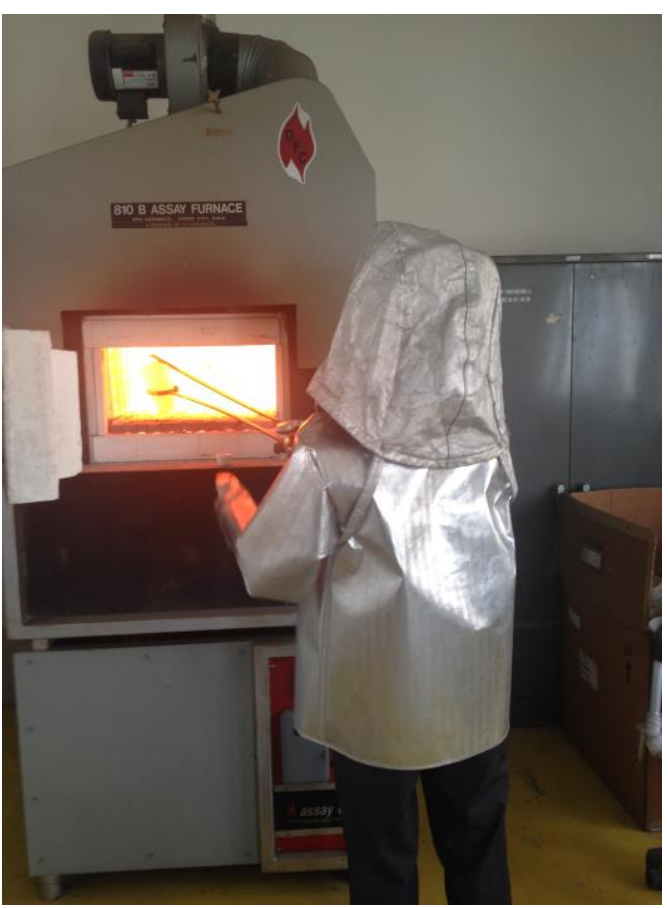

(a)

Gambar 1

g) adalah komponen fluks. Alur pengerjaan fire assaying mengacu pada hasil penelitian terdahulu $^{16)}$ bahwa fusi berlangsung pada $1100^{\circ} \mathrm{C}$ selama satu jam sedangkan kupelasi pada $850^{\circ} \mathrm{C}$ selama 45 menit. Hasil akhir dari proses fire assay adalah agregat $\mathrm{PGM}+\mathrm{Au}$ (prill) yang telah dipisahkan dari lead button (Gambar 1b) untuk dipreparasi sebelum analisis dengan ICP-MS. Prill hasil fire assay dari sampel ditimbang untuk kemudian dilarutkan dengan campuran asam karena prinsip dasar analisis ICP-MS adalah pengukuran kadar sampel dalam bentuk larutan. Asam flourida (HF), asam perklorat $\left(\mathrm{HClO}_{4}\right)$, asam klorida $(\mathrm{HCl})$, dan asam itrat $\left(\mathrm{HNO}_{3}\right)$ adalah empat jenis asam yang dipergunakan dalam skala suprapure. Perlu diperhatikan bahwa peralutan dengan asam juga berarti bahwa contoh telah melewati proses pengenceran. Lima tingkat konsentrasi larutan pada pembuatan kurva kalibrasi yang kelak akan menjadi dasar penentuan limit deteksi adalah 0,1 ppb, 0,5 ppb, 2,5 ppb, 10 ppb, dan 25 ppb. Skema penelitian dapat diperhatikan pada Gambar 2.

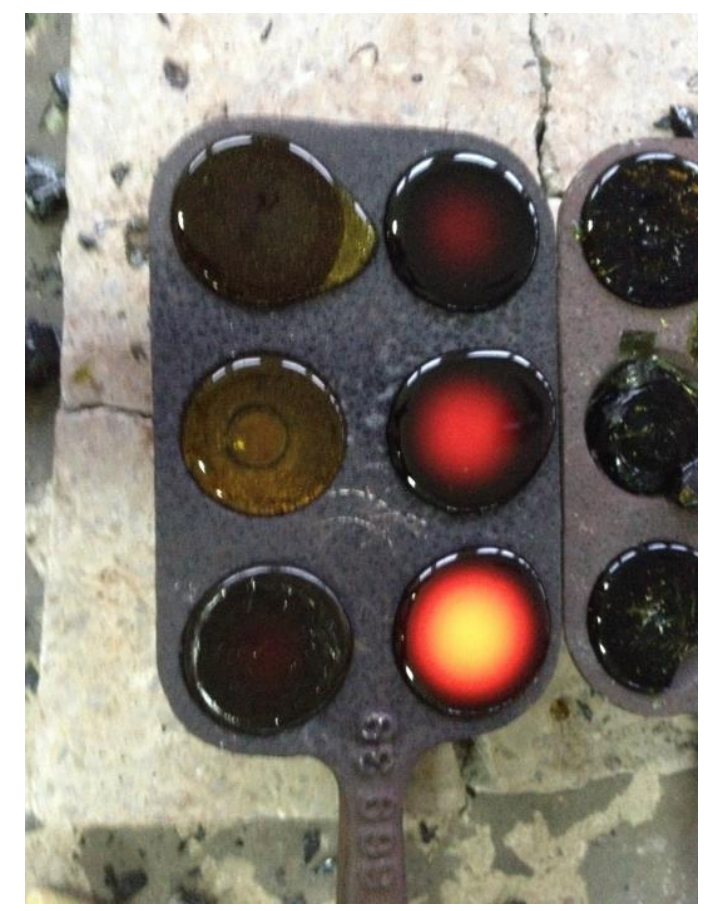

(b)

Skema fire assay: a) pakaian pelindung khusus dibutuhkan pada prosedur fire assay karena melibatkan temperatur $>800^{\circ} \mathrm{C}$; dan b) $\mathrm{Pb}$-button hasil pemanasan sampel dan fluks dalam tungku fire assay. 


\section{HASIL DAN PEMBAHASAN}

\section{Limit Deteksi}

Secara sederhana, kurva kalibrasi disimpulkan makin linear jika nilai slop makin mendekati 1. Persamaan (1) dipergunakan dalam pembuatan kurva regresi linear pada pengukuran larutan kalibrasi ${ }^{22,23)}$, dimana parameter $\mathrm{y}, \mathrm{x}, \mathrm{a}$, dan $\mathrm{b}$ masing-masing adalah respon hasil pengukuran, respon yang seharusnya diperoleh, slop kurva, dan intersep. Standar deviasi kurva kalibrasi $\left({ }^{S y} y_{l x}\right)$ diperoleh dengan menggunakan persamaan (2), sehingga limit deteksi berdasarkan respon pembacaan alat adalah tiga kali nilai standar deviasi kurva kalibrasi dengan persamaan (3). Dengan $\bar{\chi}$ dan $n$ sebagai rerata dan jumlah tingkat larutan kalibrasi, LOD secara konsentrasi diketahui dengan persamaan (4). Intersep positif bermakna bahwa sesungguhnya analit telah dapat terdeteksi pada limit dibawahnya. Pada sisi lain, intersep negatif menunjukkan bahwa level limit deteksi sebelumnya masih belum cukup untuk menganalisis suatu analit ${ }^{24,25)}$. Dengan demikian, intersep hanya diperhitungkan bila bernilai negatif, namun dapat diabaikan bila bernilai positif. Hasil pengukuran larutan kalibrasi ditampilkan pada Tabel 1.

Dengan persamaan (1)-(4) maka limit deteksi Pd adalah 2,29 ppb. Linearitas kurva kalibrasi tampak sangat baik (sangat mendekati 1) dengan slop pada analit Pd bernilai 1,0057 ppb sebagaimana ditampilkan Gambar 3. Tiga kali pengulangan pada pengukuran larutan kalibrasi berguna untuk menelusuri tingkat kestabilan pengukuran. Penggunaan persamaan (3) untuk mengukur deviasi pada tiga kali pengukuran menunjukkan bahwa pengukuran sangat stabil rentang deviasi 0 $1,96 \%$ (Tabel 1.).

$y=a x+b$

$S y_{l_{x}}=\sqrt{\frac{\sum_{i}^{M_{1}^{2}\left(x_{i}-Z\right)^{2}}}{n-2}}$

$y_{L O D}=3 \times S y_{V_{x}}$

$L O D=\left(\left(3 \times S y_{d x}\right) \div a\right)+(b \div a)$

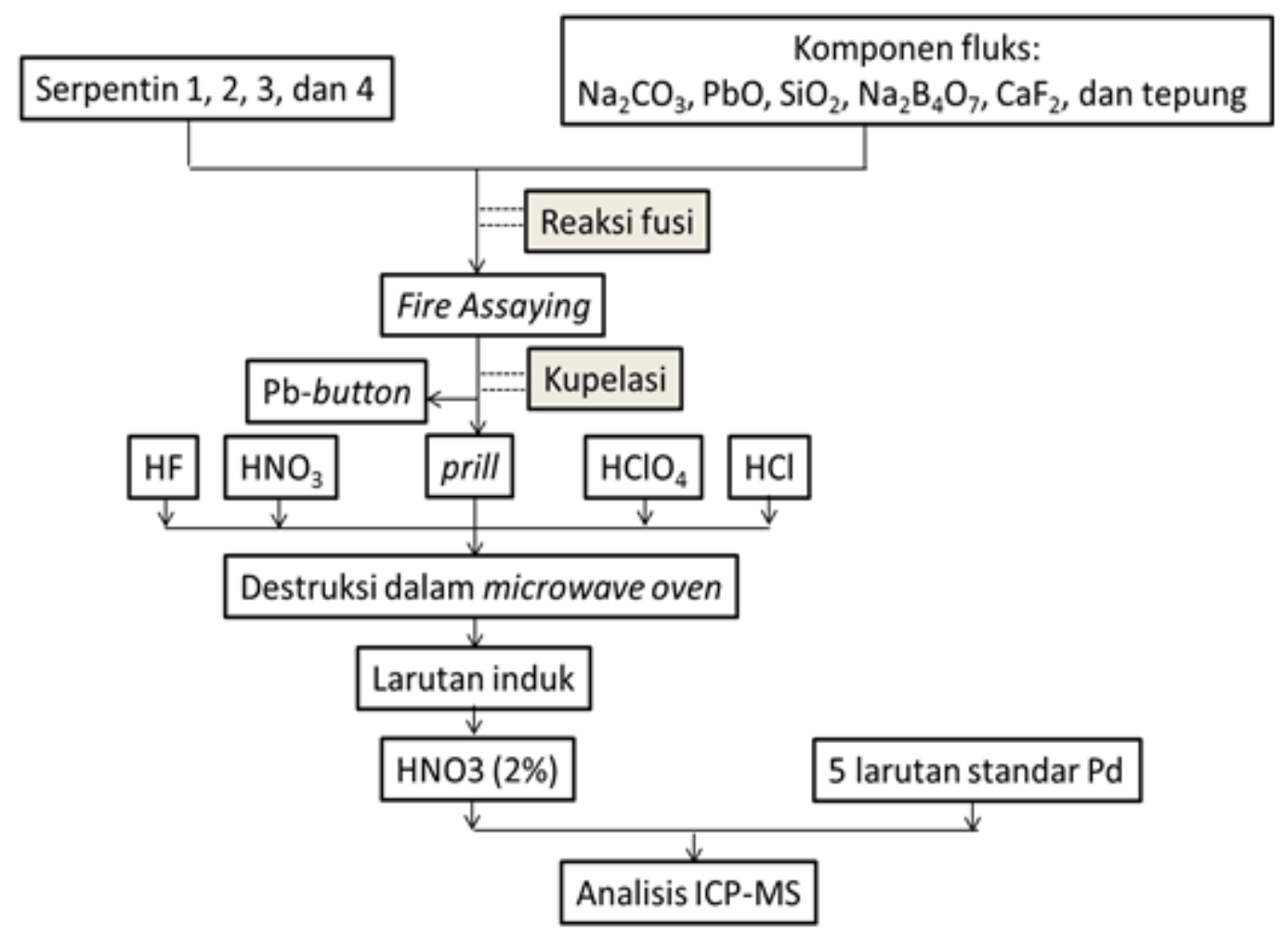

Gambar 2.

Skema pra-konsentrasi sampel hingga analisis Pd menggunakan ICP-MS pada studi ini. 


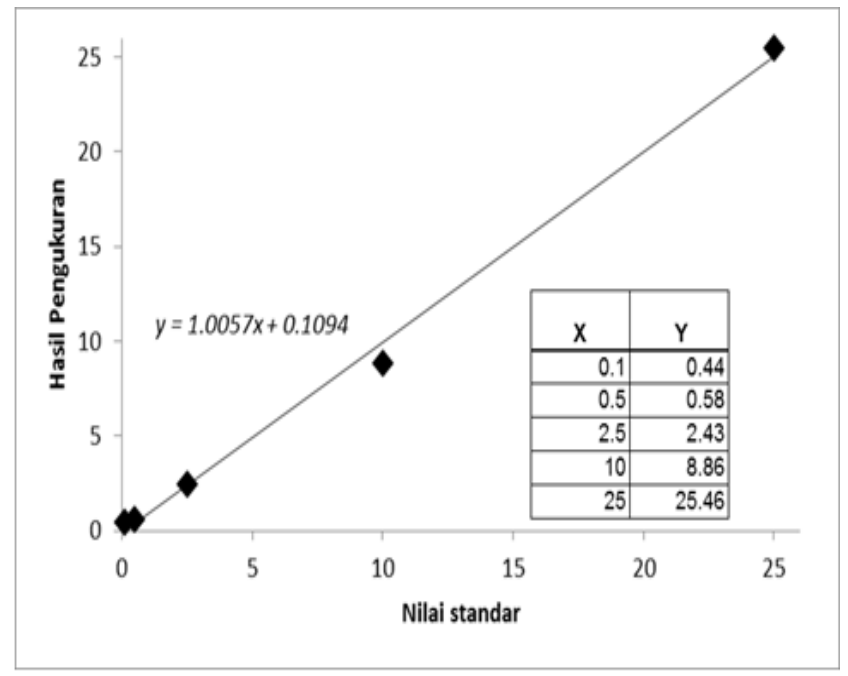

Gambar 3.

Kurva kalibrasi penentuan limit deteksi Pd pada penelitian ini.

Tabel 1.

Hasil pengukuran pada lima tingkat konsentrasi diagram kalibrasi

\begin{tabular}{lll}
\hline Konsentrasi & \multicolumn{1}{c}{ Hasil Pengukuran $(\mathbf{p p b})$} \\
\hline \multirow{3}{*}{$0,1 \mathrm{ppb}$} & Pengukuran -1 & 0,09 \\
& Pengukuran -2 & 0,09 \\
& Pengukuran -3 & 0,09 \\
& rerata \pm deviasi & 0,09 \\
\cline { 2 - 3 } $0,5 \mathrm{ppb}$ & Pengukuran -1 & 0,51 \\
& Pengukuran -2 & 0,5 \\
& Pengukuran -3 & 0,53 \\
& rerata \pm deviasi & $0,51 \pm 0,01$ \\
\cline { 2 - 3 } $2,5 \mathrm{ppb}$ & Pengukuran -1 & 2,76 \\
& Pengukuran -2 & 2,75 \\
& Pengukuran -3 & 2,82 \\
& rerata \pm deviasi & $2,77 \pm 0,03$ \\
\cline { 2 - 3 } $10 \mathrm{ppb}$ & Pengukuran -1 & 9,63 \\
& Pengukuran -2 & 9,68 \\
& Pengukuran -3 & 9,57 \\
& rerata \pm deviasi & $9,63 \pm 0,04$ \\
\cline { 2 - 3 } $25 \mathrm{ppb}$ & Pengukuran -1 & 25,24 \\
& Pengukuran -2 & 25,36 \\
& Pengukuran -3 & 24,76 \\
\hline & rerata \pm deviasi & $25,12 \pm 0,26$ \\
\hline
\end{tabular}

\section{Akurasi Pengukuran}

Akurasi pengukuran perlu diketahui untuk menjamin tingkat kebenaran hasil analisis ${ }^{22,25,26)}$. Perbandingan hasil analisis certified reference material (CRM) yang telah diproses melalui tahapan yang sama dengan sampel terhadap nilai referensinya sering digunakan untuk mengetahui tingkat akurasi ${ }^{19,26)}$. Namun demikian, studi ini menggunakan metode spiking karena Laboratorium Geologi belum memilki CRM untuk analit Pd. Seperti disebutkan sebelumnya metode ini juga cocok untuk pengukuran analit dengan kelimpahan sangat sedikit. Spike recovery $\left(\mathrm{S}_{\mathrm{R}}\right)$ sebagai derajat akurasi metode spiking dihitung dengan persamaan (5) berikut:

$S_{R}(\%)=\left(\left(\mathrm{C}_{\text {spike }}-\mathrm{C}_{\text {spl }}\right) / \mathrm{Cl}\right) \times 100 \%$

$\mathrm{C}_{\text {spike }}$ merupakan konsentrasi pada sampel yang telah di-spike, $\mathrm{C}_{\mathrm{spl}}$ sebagai konsentrasi pada sampel, dan $\mathrm{Cl}$ adalah konsentrasi bahan spike yang ditambahkan 
pada sampel. Hasil pengukuran terhadap empat sampel dalam penelitian ini terangkum pada Tabel (2).

Meski dipreparasi dengan proses yang sama, terdapat perbedaan yang cukup besar pada hasil analisis dua sampel standar internal Serpentin (percobaan-1 dan percobaan-2). Paladium pada percobaan pertama terdeteksi sebesar 54 ppb sedangkan pada percobaan kedua jauh lebih rendah (34 ppb). Rentang perbedaan ini dapat disebabkan oleh proses assaying yang belum sempurna pada Serpentin(II) sehingga belum seluruh analit $\mathrm{Pd}$ terpisahkan dari pengotornya dan terperangkap dalam lead button. Spike recovery yang nyaris sempurna (100,76\%) ditunjukkan oleh percobaan ke-3 yaitu dengan penambahan 2500 ppb analit Pd kepada sampel Serpentin(I). Percobaan ke-4 dideskripsikan sebagai hasil analisis $\mathrm{Pd}$ dalam sampel Serpentin(II) dengan adisi
5000 ppb analit Pd. Namun demikian, spike recovery pada percobaan ke-4 (112\%) kurang presisi dibandingkan dengan percobaan ke-3. Seperti dijelaskan sebelumnya bahwa serial larutan kalibrasi memiliki konsentrasi terendah $0,1 \mathrm{ppb}$ dab tertinggi 25 ppb. Urutan proses prakonsentrasi fire assay dan pelarutan asam sebelum analisis menggunakan ICP. MS menyebabkan bahan telah mengalami pengenceran 500 kali. Oleh sebab itu, kurva kalibrasi valid untuk konsentrasi Pd dalam sampel antara 50 ppb hingga 12.500 ppb. Konsentrasi Pd pada Serpentin(II) terdeteksi 34 ppb yang berada sedikit di bawah rentang validitas kalibrasi. Perbaikan berikutnya dapat dilakukan dengan memperlebar rentang serial larutan kalibrasi sehingga dapat dianggap valid untuk menganalisis kisaran kadar analit yang lebih luas.

Tabel 2.

Hasil analisis Serpentin tanpa adisi maupun dengan spiking $\mathrm{Pd}$

\begin{tabular}{llccc}
\hline No & Keterangan & Adisi Pd $(\mathrm{ppb})$ & Hasil Analisis Pd $(\mathrm{ppb})$ & $S_{R}(\%)$ \\
\hline 1. & Serpentin(I) & - & 54 & - \\
2. & Serpentin(II) & - & 34 & - \\
3. & Serpentin(I)+spike & 2500 & 2573 & $100,76 \%$ \\
4. & Serpentin(II)+spike & 5000 & 5632 & $111,96 \%$ \\
\hline
\end{tabular}

\section{SIMPULAN}

Standarisasi analisis Pd dengan ICP-MS dan pra-konsentrasi dengan fire assay menunjukkan limit deteksi yang baik pada 1,0057 ppb. Pengulangan pengukuran terhadap larutan kalibrasi menunjukkan kestabilan perangkat dengan rentang deviasi $0-1,96 \%$. Perbedaan hasil dua kali pengukuran standar internal Serpentin dapat disebabkan oleh proses pra-konsentrasi yang belum sempurna. Metode spiking diterapkan untuk mengetahui derajat akurasi proses analisis akibat ketiadaan CRM dan konsentrasi alamiah analit $\mathrm{Pd}$ yang rendah. Analisis disimpulkan akurat dengan spike recovery $100,76 \%$ dan $111,96 \%$. Perbedaan akurasi mungkin dipengaruhi oleh kadar $\mathrm{Pd}$ pada salah satu pengukuran sampel yang sedikit lebih kecil dari batas bawah validitas kalibrasi.

\section{UCAPAN TERIMAKASIH}

Terimakasih diucapkan kepada Kepala Pusat Survei Geologi - Kementerian ESDM yang telah memberikan ijin penggunaan data pada tulisan ini. Studi ini banyak dibantu oleh saudara Deni Mundhary dan saudara Erik Nugraha pada sisi assaying. Kami sangat menghargai bantuan saudari Indah Yuni untuk bantuannya dalam preparasi dan penyiapan perangkat ICP-MS. Penulis juga mengucapkan terimakasih kepada Bapak Moh. Heri Hermiyanto Jazuli atas bimbingannya mengenai aspek geologi PGM.

\section{DAFTAR PUSTAKA}

1. Ako, T.A., Vishiti, A., Suh, C.E., Kedia, A.C., Omang, B.O., Geological Models of Platinum Group Elements (PGE) Depletion in Metamorphosed Ultramafic Rocks of the Nyong Series, Southeast Cameroon, International Journal of Mining Science, vol. 3(4), 2017, p.1-12.

2. Sverdrup, H. U., Ragnarsdottir, K. V., $A$ system dynamics model for platinum group metal supply, market price, depletion of extractable amounts, ore grade, recycling and stocks-in-use, Resources, Conservation and Recycling, vol.114, 2016, p.130-152. 
3. Balaram, V., Singh, S.P., Satyanarayanan, M., Anjaiah, K.V., Platinum group elements geochemistry of ultramafic and associated rocks from Pindar in Madawara Igneous Complex, Bundelkhand massif, central India, Journal of earth system science, vol.122(1), 2013, p.79-91.

4. Jackson-Brown, S., Scoates, J.S., Nixon, G.T., Ames, D.E., Mineralogy of sulphide, arsenide, and platinum group minerals from the $D J / D B$ Zone of the Turnagain Alaskan-type ultramafic intrusion, north-central British Columbia, Geological Fieldwork 2013, British Columbia Ministry of Energy and Mines, British Columbia Geol Surv Paper 2014-1, 2014.

5. Xing, L., Zhou, M., Qi, L., Huang, Z., Discussion on the PGE anomalies and source materials of K-bentonite (Bed 5) in the Lower Cambrian Meishucun section, Yunnan, Chinese Journal of Geochemistry, vol.34(3), 2015, p.346361.

6. O’Driscoll, B., González-Jiménez, J.M., Petrogenesis of the platinum-group minerals, Reviews in Mineralogy and Geochemistry, vol.81(1), 2016, p.489578.

7. Irzon, R., Abdullah, B., Geochemistry of Ophiolite Complex in North Konawe, Southeast Sulawesi, Eksplorium: Buletin Pusat Teknologi Bahan Galian Nuklir, vol.37(2), 2016, p.101-114.

8. Sarmili, L., Hydrothermal Mineralization in jailolo Waters, West Halmahera, North Maluku Province, Bulletin of the Marine Geology, vol.30(1), 2016, p.3543.

9. Lindley, I. D., Epithermal and arcrelated layered mafic platinum-group element mineralisation in the maficultramafic rocks of eastern Papua, Australian Journal of Earth Sciences, vol.63(4), 2016, p.393-411.

10. Aruguete, D. M., Murayama, M., Blakney, T., Winkler, C., Enhanced release of palladium and platinum from catalytic converter materials exposed to ammonia and chloride bearing solutions, Environmental Science: Processes \& Impacts, 2018.

11. Vanotti, M., Blondeau-Patissier, V., Moutarlier, V., Ballandras, S., Analysis of palladium and yttrium-palladium alloy layers used for hydrogen detection with SAW device, Sensors and
Actuators B: Chemical 2017, p.30-35, 2015

12. Rodliyah, I., Ardha, N., Saleh, N., Sariman, S., Ekstraksi Emas dari Lumpur Anoda Melalui Proses Klorinasi Basah dan Ekstraksi Pelarut, Jurnal Teknologi Mineral dan Batubara, v.13(2), 2017, p.99-111.

13. Asai, S., Yomogida, T., Saeki, M., Ohba, H., Hanzawa, Y., Horita, T., Kitatsuji, Y., Determination of 107Pd in $P d$ Recovered by Laser-Induced Photoreduction with Inductively Coupled Plasma Mass Spectrometry, Analytical Chemistry, vol.88(24), 2016, p.1222712233.

14. Irzon, R., Kurnia, K., Kondisi Temperatur, Waktu, dan $\mathrm{pH}$ reaksi untuk Mengoptimasi Prosedur Standar Analisa Platinum dengan Ekstraksi Atomic Absorption Spectrometry, Jurnal Geologi dan Sumberdaya Mineral, vol.14(4), 2013, p.51-58.

15. Irzon, R., Kurnia, K., Perbandingan Analisis $\mathrm{Ni}$ dalam Batuan Beku Menggunakan AAS, ICP-MS, dan XRF, Publikasi Sarana Teknik Pusat Survei Geologi - Kementerian ESDM, 2016, p.9-20.

16. Irzon, R., Kurnia, K., Optimasi Teknik Fire Assay dan Kondisi Kupelasi untuk Memperoleh Komposisi Fluks Terbaik pada Analisis Kadar Emas, Jurnal Geologi dan Sumberdaya Mineral, vol.15(1), 2014, p.55-62.

17. Tambunan, B., Supriyadi, C., Juliansyah, J., Desain dan Simulasi Tungku Bakar untuk Pengolahan Pasir Besi Menjadi Sponge Iron dengan Teknologi Tunnel Klin, Majalah IImiah Pengkajian Industri, vol.10(1), 2016, p.51-60.

18. Permatasari, N. V., Kawigraha, A., Hapid, A., Wibowo, N., Identifikasi Perubahan Mineral Selama Proses Pemanasan Pelet Komposisi Nikel dengan Analisis Difraksi Sinar $X$, Majalah IImiah Pengkajian Industri, vol.12(1), 2018, p.9-16.

19. Carpentier, M., Gannoun, A., Pin, C., Sigmarsson, O., New Thorium Isotope Ratio Measurements in Silicate Reference Materials: A-THO, AGV-2, $B C R-2, \quad B E-N, \quad B H V O-2$ and BIR-1, Geostandards and Geoanalytical Research, vol.40(2), 2016, p.239-256. 
20. Jweda, J., Bolge, L., Class, C., Goldstein, S. L., High Precision $\mathrm{Sr}-\mathrm{Nd}$-Hf-Pb Isotopic Compositions of USGS Reference Material BCR-2, Geostandards and Geoanalytical Research, vol.40(1), 2016, p.101-115.

21. Szymanowski, D., Fehr, M. A., Guillong, M., Coble, M. A., Wotzlaw, J. F., Nasdala, L., Schönbächler, M., Isotopedilution anchoring of zircon reference materials for accurate Ti-in-zircon thermometry, Chemical Geology, vol. 481, 2018, p.146-154.

22. Prabowo, M. H., Wibowo, A., Yuliani, F., Identifikasi Dan Analisis Akrilamida Dalam Kopi Serbuk (Tubruk) dan Kopi Instan Dengan Metode Kromatografi Cair Kinerja Tinggi, Jurnal IImiah Farmasi, vol.9(1), 2016.

23. Kuncoro, B., Uji Kesesuaian Sistem Kromatografi Cair Kinerja Tinggi Fase Terbalik pada Bahan Baku Parasetamol, Jurnal Farmagazine, vol.1(2), 2017, p.35-41.
24. Kruve, A., Rebane, R., Kipper, K., Oldekop, M. L., Evard, H., Herodes, K., Ravio, P., Leito, I., Tutorial review on validation of liquid chromatographymass spectrometry methods: Part I, Analytica Chimica Acta, vol.870, 2015, p.29-44.

25. Irzon, R., Pembuatan Material Acuan Internal Berupa Batuan Pada Zona Kaolinisasi dari Kokap Kulon Progo Menggunakan ICP-MS, Jurnal Standardisasi, vol.19(2), 2018, p.103112.

26. Verni, E. R., Londonio, A., Bazán, C., Strasser, E., Perino, E., Gil, R. A., REE profiling in basic volcanic rocks after ultrasonic sample treatment and ICPMS analysis with oxide ion formation in ICP enriched with $\mathrm{O}_{2}$, Microchemical Journal, vol.130, 2017, p.14-20. 